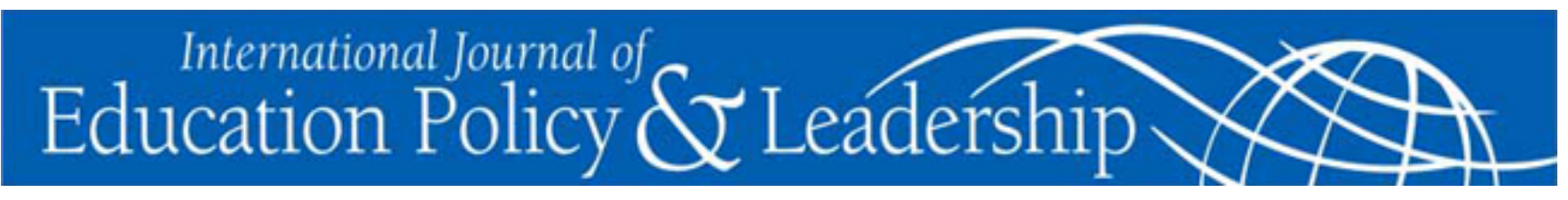

\title{
Gubernatorial Rhetoric and the Purpose of Education in the United States
}

\author{
DiCK M. CARPENTER \\ University of Colorado, Colorado Springs \\ HANING HUGHES \\ United States Air Force Academy
}

\begin{abstract}
For decades, scholars have debated the purpose of U.S. education, but too often ignored how power brokers outside of the educational arena define education or the consequences of those definitions. This study examines how one of the most prominent categories of U.S. leaders, state governors, defines education and discusses the policy implications. We examine gubernatorial rhetoric-that is, public speeches_about education, collected from State of the State speeches from 2001 to 2008. In all, one purpose gains overwhelmingly more attention-economic efficiency. As long as governors and the general public, seen enthymematically through gubernatorial rhetoric, define education in economic terms, other purposes will likely remain marginalized, leading to education policies designed disproportionately to advance economic ends.
\end{abstract}

Carpenter, D. M., \& Hughes, H. (2011). Gubernatorial rhetoric and the purpose of education in the United States. International Journal of Education Policy and Leadership 6(6).

For decades, scholars have written extensively on and debated different purposes of education in the United States (Barber, 1992, 1997; Bass, 1997; Boyer, 1983; Butts, 1975-1976; Conant, 1959; Endres, 2006; Goodlad, Mantle-Bromley, \& John, 2004; Gutmann, 1999; Heller, 2007; Kaestle, 1983, 2000; Kohn, 2002a; Labaree, 1997; Lin, 2006; Mourad, 2001; Novak, 2002; Postman, 1995; Proefriedt, 2001). Yet, while the debate continues in education circles, scholars too often ignore the fact that education's purposes are simultaneously being defined by those outside the educational arena. These individuals and groups sometimes have as much or more influence over the definitions than those inside. They include, among others, U.S. presidents, members of Congress, state legislators, and-the topic of this paper-state governors.

For educational policymaking, how governors and other policy leaders define the purposes of education is significant, as these purposes substantively contribute to the types of policies these leaders pursue. According to Weber's famous 1946 dictum, ideas have profound effects on the course of events. Contemporary theorists likewise discuss how ideation plays an important role in the decisions of policymakers (Campbell, 2002; Child, 1994; Davidson, 1963; Heil \& Mele, 1993; Holsti, 1976; Yee, 1996). Therefore, this makes the study of ideation an important pursuit in understanding policy creation, implementation, and outcomes.

In education specifically, Moses (2002) and others (Jackson \& Kingdon, 1992; Kelman, 1988; McDonnell, 1991; Verba \& Orren, 1985) conclude that philosophical positions drive educational policymaking, which means that what politicians believe about education's purposes should be important to education scholars. Yet, to date, how policymakers define educational purpose remains relatively unexplored in a systematic fashion. Therefore, we seek to contribute to a greater understanding of this issue by considering how state governors in the United States define the purposes of education and what this means for educational policymaking. 


\section{Literature review}

Scholarship examining how U.S. policymakers of all types define the purposes of education appears particularly slim when compared to the vast literature generated by academics and pundits. The literature focused specifically on gubernatorial values about education dwindles almost to nothing, with a few scant discussions in articles focused on related topics (Michael, 2006; Zoracki, 2006). The closest streams of research include discussions of the governor's role in educational policymaking, the function of agendasetting, and gubernatorial leadership through rhetoric, herein defined as verbal communication or public speech intended to persuade (Woolf, 1981). The review below briefly addresses each and then concludes with the working definitions of educational purpose used in this study.

Examinations of state governors in the United States often begin by acknowledging the central role the office plays in state politics and policymaking. As the pinnacle of each state's governmental hierarchy, the governor personifies the state to many (Gross, 1991; Herzik \& Brown, 1991; Rosenthal, 1990). As such, the state legislature, bureaucracy, press, politics, and policies are affected by the governor (Beyle, 1999; Jewell, 1972; Morehouse, 1998), including educational policymaking (Conley, 2003; Fusarelli, 2005). One should not underestimate the power of the legislature, of course, particularly in some states where the governor is considered constitutionally weak (Dometrius, 1987). But in education, at least, governors play a highly influential policy role. In fact, according to Education Next, "Governors from New York to California aspire to be known as the "education governor"' ("The Education Governor," 2007). To don the mantle, governors often make education their top legislative priority and operate as key players in initiating and overseeing a variety of education policies (Fusarelli, 2002, 2005; Mazzoni, 1995; Wixson, Dutro, \& Athan, 2003).

\section{Gubernatorial agenda-setting and rhetoric}

According to gubernatorial scholars, the governor's primary powers are contained in the roles of director of budgets, principal personnel officer, and chief legislator, particularly the latter (Bernick \& Wiggins, 1991; Jewell, 1972). Governors fulfill the chief legis- lator role primarily through agenda-setting (Cusick \& Borman, 2002; DiLeo, 1996), understood here as the act of articulating directions and goals the governor wishes to emphasize (Kingdon, 1995). According to van Assendelft (1997), the governor's philosophy is more important than any other consideration in selecting agenda items. Factors such as cost, both monetary and political, do not come into play until the selection of specific policy alternatives. Yet, according to Coffey (2005), few studies have attempted to measure governors' policy ideologies generally, and this is no different for education policy.

The most common vehicle for gubernatorial agenda setting is public rhetoric (Crew, 1992; DiLeo, 1997c), for governors, like other policymakers, enact power through language (Marshall, Mitchell, \& Wirt, 1985). According to Mazzoni (1995), "More than any other state actor, they [have] the institutional authority, organizational resources, and media access to dramatize need, frame issues, and set agendas" (p. 61). Of those, framing, which is how leaders define the normative and sometimes cognitive ideas located in the foreground of policy debates (Fairhurst \& Sarr, 1996; Schon, 1994), is one of the most significant vehicles by which governors advance policy ideas.

For example, Governor Kunin (1990) of Vermont describes her use of public rhetoric in framing and shaping educational reform:

My first step was to make the best possible use of the bully pulpit. At no time does a governor receive more exclusive attention than when giving [the]...state of the state speech.... In addition to enacting legislation, I was able to raise the public awareness of the value of education. On one level, a governor-any political leader-personifies values. I do not think that values can be an overlay, added on to speeches because a pollster indicates that certain values are in vogue. (p. 51-52)

\section{Educational purpose}

Scholars who have examined the articulation of educational purpose in the United States through policy documents or the words of policymakers note diverse and multitudinous purposes. This grows out of 
Willis's 1961 observation that since at least the founding of the United States, education has been designed to serve society's needs. Whenever an objective has been judged desirable for the individual or society, it has tended to be accepted as a valid concern of the school. As a result, schools have routinely operated under multiple purposes.

Such multiple purposes are reflected in the rhetoric of policymakers. For example, in a recent study of how U.S. presidents define the purposes of education, Carpenter (2005) discerned four broad purposes: economics, citizenship, self-realization, and human relationship. Through content analysis of State of the Union and inaugural speeches, Carpenter found economics and citizenship garnered the most attention, but the mention of the purposes differed over time: citizenship prevailed until the early 1900s, and economics grew prominent in presidential rhetoric throughout the 20th century. Given its close alignment to our study on gubernatorial rhetoric, Carpenter's literature - and rhetoric-based classifications and definitions of educational purpose provide an instructive and useful structure for this study (see Carpenter's 2005 article for a more thorough discussion).

Self-realization. To fulfill this purpose, educators strive to develop each individual's abilities, curiosity, and creativity. Such efforts contribute not only to the individual's development of self, but also to her or his place in the community (Beane, 1998). The relationship is circular-self-realization equips one to function socially, politically, and economically, which, in turn, builds a greater sense of self (Hartoonian, 1999).

Human relationship. In fulfilling the purpose of human relationship, schooling seeks to resolve the tensions between individual freedom and social equality. Through respect for justice, an awareness of the balance between social ideals and reality, and acknowledgment of our commonality in the human condition, we better understand and can act upon the human relationship purpose. Dewey (1927) referred to this as "community."

Economic efficiency. Throughout the history of the United States, schools have promoted the prevailing economic virtue-capitalism. Yet capitalism is more than a system of economy. It is, in a sense, a philosophical system involving ideas about human nature, the existence and operation of natural law, and the source of character and values (Wingo, 1965). This system of thought has profoundly shaped minds, values, and schools in the United States.

Civic responsibility. Typically, this is described as education for democracy, but, as Wells, Slayton, and Scott observe, "Virtually all writers and speakers tend to use the word 'democracy'... but rarely do they specify what exactly they mean" (2002, p. 340). When they finally attempt to define it, many end up at around the same place-civic responsibility. Wingo (1965), Engel (2000), and Labaree (1997) describe it as enlightening students to prepare them for their role as citizen-leaders.

Using these same educational purposes, our study examines how state governors define the purposes of education for their respective states. Like Carpenter's (2005) work on U.S. presidents, this paper uses gubernatorial state of the state speeches from 2001 to 2008 to discern overall patterns and trends over time. Results indicate that as with modern presidents, governors appear to define education in economic terms more than any other, regardless of political party, region, time, or other factors.

\section{Methods}

\section{Questions}

In examining how governors define education, our analysis used a mixed-methods approach in two phases. The first was a content analysis of State of the State (SOS) speeches from 2001 to 2008. The second used time series regression to discern differences in educational purpose, given an index of factors. Our research was guided by the following questions:

1. How do governors define the purposes of education?

2. Which purposes, if any, have been given greater emphasis?

3. Are there significant differences in educational purpose across years and also based on governors' party, region, and economic and social factors present within the respective states?

These questions naturally lent themselves to and benefited from a mixed-methods approach. As described below, discerning and defining educational 
purpose from textual data required qualitative content analysis, and examining differences over time and based on the aforementioned factors was completed via time series analysis.

\section{Data}

Phase I data for this study came from gubernatorial SOS speeches for all 50 governors from 2001 to 2008, available in full text from the Stateline.org website. Although governors give many speeches and produce numerous public documents, the SOS constitutes one of the most significant occasions of gubernatorial rhetoric from which one can reliably infer a macroscopic story (Bernick \& Wiggins, 1991; DiLeo, 1997b).

These speeches are the most widely reported of gubernatorial rhetoric. Governors routinely present them to the state legislature in the early part of the year, usually at the beginning of the legislative session, if there is one, making them comparable units of analysis across states and across time (Coffey, 2005). In virtually all cases, governors, through the
SOS, attempt to set the agendas for the legislatures (Bernick \& Wiggins, 1991; DiLeo, 1997c). Governors also frequently strive to set the tone for the executive branch and occasionally try to persuade the public to behave in certain ways or support particular initiatives. Finally, they may take the occasion to urge local governments, other states, and the federal government to follow certain recommendations (DiLeo, 1997b).

Although governors, throughout the year, may pursue policies not contained within the SOS, the speeches are the closest approximation and provide an excellent gauge of a governor's agenda and policy philosophies (Ferguson, 2003; van Assendelft, 1997). Moreover, the contents of SOS speeches are usually translated into administration bills and introduced by the governor's party leaders (McCally, 1972; Rosenthal, 1990). Thus, many gubernatorial researchers use SOS addresses as sources of data (Coffey, 2005; Crew, 1992; DiLeo, 1997a, 1997b, 1997c; DiLeo \& Lech, 1998; Herzik, 1983; Kiser \& Monroe, 1992; van Assendelft, 1997).

Table 1: Descriptive Statistics for Time Series Analysis

\begin{tabular}{llcccccccc}
\hline \multirow{2}{*}{ Crime Rates } & & 2000 & 2001 & 2002 & 2003 & 2004 & 2005 & 2006 & 2007 \\
\% DNWNS & $m$ & 0.040 & 0.040 & 0.040 & 0.078 & 0.077 & 0.038 & 0.037 & 0.036 \\
& $S D$ & 0.009 & 0.009 & 0.010 & 0.020 & 0.020 & 0.009 & 0.009 & 0.009 \\
\% Voter Turnout & $m$ & 0.137 & 0.141 & 0.147 & 0.147 & 0.140 & 0.150 & 0.140 & 0.143 \\
& $S D$ & 0.046 & 0.036 & 0.033 & 0.037 & 0.032 & 0.033 & 0.034 & 0.033 \\
Unemployment Rate & $m$ & 0.525 & 0.462 & 0.398 & 0.490 & 0.581 & 0.493 & 0.404 & 0.500 \\
& SD & 0.069 & 0.067 & 0.073 & 0.068 & 0.072 & 0.073 & 0.081 & 0.069 \\
& & 3.837 & 4.474 & 5.326 & 5.553 & 5.151 & 4.878 & 4.405 & 4.321 \\
& $S D$ & 0.899 & 0.872 & 1.007 & 1.047 & 0.991 & 1.050 & 1.007 & 1.005 \\
\hline Governors' Party & & 2001 & 2002 & 2003 & 2004 & 2005 & 2006 & 2007 & 2008 \\
\hline \multirow{3}{*}{ Region } & Democrat & 19 & 24 & 22 & 22 & 21 & 21 & 28 & 27 \\
& Republican & 29 & 26 & 28 & 28 & 29 & 29 & 22 & 23 \\
& Northeast & 11 & & & & & & & \\
& Midwest & 12 & & & & & & & \\
\hline
\end{tabular}

*Continuous data are presented in original, untransformed format

Phase II independent variable data and their descriptive statistics are reported in Table 1. Given the categories of purposes analyzed in the SOS speeches and their designation as dependent measures in Phase II, we identified an indicator aligned with each purpose that represented the respective conditions 
within a state. Similar to Burden and Sanberg (2003), we did so to examine whether governors' purposes for education differed or changed in response to prevailing conditions within the states. The measure of a state's economy (aligned with economic efficiency) was its unemployment rate (Dua, Miller, \& Smyth, 1999; Hansen, 1999), taken from the U.S. Bureau of Labor Statistics. Crime rates, collected from the Federal Bureau of Investigation's Uniform Crime Reports, represent all crimes included in the reports (felonies, property crimes, etc.) and aligned with the human relationship purpose (Jacobs \& Carmichael, 2001). Voter turnout percentages were taken from the United States Elections Project and aligned with the civic responsibility purpose (Goetz \& Rupasingha, 2006; Rupasingha, Goetz, \& Freshwater, 2006). The final indicator is the percentage of 18- to 24-yearolds in each state who dropped out of school, were not working, and were not in school (DNWNS). These data were drawn from the Annie E. Casey Foundation Kids Count Data Center and aligned with the self-realization purpose under the premise that dropping out of school, not working, and not attending schooling indicates a low level of the realization of personal potential (Kaplan, Damphousse, \& Kaplan, 1996; Sweeten, Bushway, \& Paternoster, 2009). This indicator is listed as a youth risk factor in the Annie E. Casey Foundation database.

In addition to prevailing conditions within a state, we also examined whether purposes differed based on the governors' political party and region of the state. Party data were gathered from the National Conference of State Legislatures website, a national nonprofit that focuses on politics and policy in state governments. Regional designations represent those used by the U.S. Census Bureau and were taken from their website.

\section{Analysis}

Phase I used content analysis to discern and code educational purposes in SOS speeches (Holsti, 1969; Moen, 1988; Weber, 1985). Consistent with procedures defined specifically by Neuendorf (2002) and operationalized in this genre by authors such as Coffey (2005), DiLeo (1997b, 1997c, 1998), Gillies (2008), and Herzik (1983), we collected the sections of all the speeches studied herein that addressed education. From these, we gleaned those sections in which governors defined a purpose or purposes for education. This exercise resulted in a sample of 358 speeches (it is not 400 because not all governors give SOS speeches each year) and 560 phrases in which a purpose of education was identified. Although some use words (Burden \& Sanberg, 2003) or sentences (Coffey, 2005) as the unit of analysis in research of this type, we adopted Miller's and Stiles's (1986) use of phrases as the unit of analysis. Words did not always adequately contain ideological meaning and sentences sometimes contained more than one purpose, making phrases the most appropriate unit.

The passages were coded deductively using the same codes used in prior research discerning educational purpose in presidential State of the Union speeches (Carpenter, 2005): self-realization, human relationship, economic efficiency, and civic responsibility, each of which was briefly defined above. Phrases were assigned only one code. The coding was then subjected to inter-rater reliability. Consistent with standard inter-rater reliability procedures (Stemler, 2004), two raters analyzed 15 percent of the total sample of phrases and showed near-perfect consensus (percent agreement=98, Cohen's Kappa $=.97, p=.005)$. By way of an example of how the phrases were coded by the raters, Table 2 (page 7) includes a sample of speech passages with coded phrases underlined. The codes assigned by the raters (consistently in all cases) are in the third column.

At the completion of coding the entire sample, we summed the number of times each purpose was mentioned by governors from 2001 to 2008. Consistent with Coffey (2005), we converted these to percentages of the total number of phrases and also calculated annual means for each purpose. Finally, we used one variable chi-square to test the distribution of frequencies across purposes. Because there is no a priori theoretical or mathematical distribution of expected values, we used an equal distribution of frequencies, a method used by others in similar research (Ramirez, Carpenter, \& Guzman, 2007). In the interpretation of results, we perceive greater frequencies per purpose as greater importance ascribed to the purpose by the governor. This is built on the theory that if a person talks more about a certain value than another, he or she has a greater concern with that value (Burden \& Sanberg, 2003; DiLeo, 
1997c; Hart, 2000; Namenwirth \& Lasswell, 1970; Weber, 1985).

Phase II used a pooled time series analysis of educational purpose with the aforementioned independent variables. The motivation for this analysis was twofold. First, we sought to discern any discursive shifts in educational purpose. Second, and related to the first, the regression analysis enabled us to explore the relationship between gubernatorial rhetoric and social and economic exigencies (Edwards \& Nicoll, 2001; Jones \& Thomson, 2008). As Edwards and Nicoll note,
In rhetorical analysis, there is an identification of the exigence, which thereby contextualizes and locates the discursive or textual practice. In policy analysis, the exigence would be that to which policy is being addressed-lack of economic competitiveness, social exclusion, lack of participation, inequality of participation, etc. Part of that contextualization is to establish the timeliness and appropriateness of the particular intervention. (p. 105)

Table 2: An Example of Coding by Raters

\begin{tabular}{lll}
\hline State/Year & Passage & Coding \\
\hline Alabama, 2002 & $\begin{array}{l}\text { I believe that every child in Alabama, regardless of where } \\
\text { they're born or to whom, regardless of the color of their skin, }\end{array}$ & \\
& whether they're rich or poor, every child in Alabama should \\
& have the chance to reach their God-given potential through & \\
& education. & \\
\hline Alabama, 2006 & $\begin{array}{l}\text { But, as I've said before, the most important economic develop- } \\
\text { ment issue in this state is and always will be education. That's }\end{array}$ & \\
& $\begin{array}{l}\text { why improving education must remain our number one mis- } \\
\text { sion. }\end{array}$ & \\
\hline Illinois, 2004 & $\begin{array}{l}\text { The more involved you are with your community the better a } \\
\text { citizen you become. That's why I am proposing legislation that }\end{array}$ & \\
& $\begin{array}{l}\text { would require all high school students in Illinois to perform } \\
\text { forty hours of community service in order to graduate. }\end{array}$ & \\
\hline Indiana, 2000 & $\begin{array}{l}\text { As we focus on academic achievement, I want to make sure } \\
\text { schools don't lose sight of some other things you have to learn }\end{array}$ \\
& $\begin{array}{l}\text { growing up: That is...a commitment to resolve conflicts } \\
\text { peaceably. }\end{array}$ & \\
\hline
\end{tabular}

Thus, the Phase II analysis enabled us to determine if gubernatorial rhetoric was a function of time and/or social and economic exigencies.

To do so, we ran four separate regressions-one for each educational purpose as the dependent variable. The regression equations took the form:

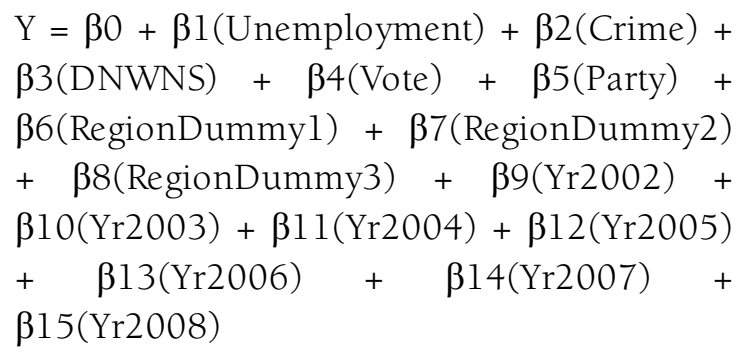

The design also lagged the unemployment, crime, DNWNS, and voter turnout variables by one period. This reflects the dynamic that SOS speeches occur early in the year so that any effects on gubernatorial rhetoric produced by such variables would be reflected in the subsequent year.

In addition, all continuous data (unemployment, crime, DNWNS, and voter turnout) were subjected to tests for stationarity and autocorrelation, two conditions common in time series data. Beginning with stationarity, statistical properties such as mean and variance may be non-constant over time and exhibit trends, cycles, random-walking, and other nonstationary behavior, confounding the measure of the relationship between variables of interest (Gujarati, 
1995; Yaffee, 2000), such as unemployment and educational purpose in this case. However, stationarity tests indicate these data were all stationary, requiring no transformations (Unemployment $\mathrm{DF}=-11.94$, $p=.000$; Voter Turnout DF=-28.25, $p=.000$; DNWNS $\mathrm{DF}=-220.81, p=.000$; Crime $\mathrm{DF}=-16.42, p=.000$ ).

Autocorrelation is a condition in which a data set is correlated with itself, offset by n-values, which likewise confounds the measure of the relationship between variables of interest. Tests for this condition, however, indicated no autocorrelation in the regression analyses (Economic Efficiency DW=1.9; Selfrealization DW=2.1; Human Relationship DW=2.1; Civic Responsibility DW=2.1). Finally, all regression analyses included tests for multicollinearity, but no remediation was necessary.

Table 3: Number and percentage of references to each educational purpose in State of the State speeches, 2001-2008

\begin{tabular}{llllll}
\hline & Economic efficiency & Self-realization & Human relationship & Civic responsibility & Total \\
\hline 2001 & $50(71 \%)$ & $13(18 \%)$ & $2(3 \%)$ & $5(7 \%)$ & 70 \\
2002 & $34(65 \%)$ & $7(13 \%)$ & $5(10 \%)$ & $6(11 \%)$ & 52 \\
2003 & $61(78 \%)$ & $11(14 \%)$ & 0 & $6(8 \%)$ & 78 \\
2004 & $24(41 \%)$ & $23(39 \%)$ & $2(3 \%)$ & $10(17 \%)$ & 59 \\
2005 & $49(58 \%)$ & $26(31 \%)$ & $3(4 \%)$ & $6(7 \%)$ & 84 \\
2006 & $37(54 \%)$ & $29(42 \%)$ & $2(3 \%)$ & $1(1 \%)$ & 69 \\
2007 & $59(66 \%)$ & $23(26 \%)$ & $4(4 \%)$ & $3(3 \%)$ & 89 \\
2008 & $34(58 \%)$ & $18(31 \%)$ & $4(7 \%)$ & $3(5 \%)$ & 59 \\
\hline Total & 348 & 150 & 22 & 40 & 560 \\
$M$ & 43.5 & 18.75 & 2.75 & 5 & $7.14 \%$ \\
Percent & $62.14 \%$ & $26.79 \%$ & $3.93 \%$ & & \\
\hline
\end{tabular}

* Percentages represent within-row percentages

\section{Results}

\section{Phase I}

From 2001 to 2008, U.S. governors emphatically defined education in economic terms far more than any other purpose (62.14 percent of phrases; the difference in distribution of phrases across purposes was statistically significant, $X^{2}=521.1, p=.0001$ ), as indicated in Table 3. Many were clear statements about the link between education and economy, such as Governor Napolitano's (AZ) 2003 statement: "I have made it clear that a solid education system is vital if we are to strengthen our economy..." In the same year, Governor Perdue (GA) likewise stated:

Knowledge is the new economic fuel, not physical labor. It is the essential ingredient for success in this information age. Providing all our citizens with the knowledge, skills and training they need to compete in the in- formation economy is the best economic development plan we can have.

The central role of education in the "new economy" enjoyed much attention as well. Governor Holden (MO) concluded: "Finally, we must make Missouri a leader in the new 'knowledge-based' economy of the future. The critical foundation of this effort-the key to Missouri's future-is-and must always be-education." Governor Granholm (MI) succinctly stated: "In the knowledge economy, business and education are linked; you cannot succeed at the former if you do not excel at the latter."

This is not to say governors defined education only in economic terms. More than 25 percent of SOS phrases were dedicated to self-realization. For example, California's Governor Gray Davis stated: "Every great human endeavor begins with a cause. Ours is, and must remain, to make every student, teacher, principal and parent in California demand more from themselves and each other than they ever believed possible." However, many gubernatorial statements made only vague references to "success," 
"opportunities," or "bright futures." Governor Henry's (OK) 2003 statement typified this: "First, our students will benefit from enhanced learning opportunities, making their future brighter." In the same year, Governor Perry (TX) opined: "Young Texans who abandon school drop out on their future. And they pay the price for it in terms of lost hopes and unfulfilled dreams," and Governor Warner (VA) described it with "...public education opens the doors of opportunity."

In terms of civic responsibility, or things close to it, only a small minority gave it attention ( 7.14 percent), and most were not particularly substantive. One example includes Delaware's Governor Minner in 2003: "As we develop our children's intellect and abilities, we should also seek to develop in them virtues that are good for them and good for society." Others linked it to character education or proposed service learning programs.

Human relationship saw even less attention, at 3.93 percent. One example includes Indiana's Governor O'Bannon, who gave passing mention (after a lengthy discussion of the education-economic tie) to the human relationship purpose:

As we focus on academic achievement, I want to make sure schools don't lose sight of some other things you have to learn growing up: That is, the life skills on which our society is based, like honesty, respect for others and respect for yourself, responsibility, and a commitment to resolve conflicts peaceably.

Within each purpose category, the aggregate findings were generally consistent across yearseconomic efficiency was always mentioned more than any other from year to year, followed by selfrealization, civic responsibility, and finally human relationship. And from year to year, the rhetoric sounded quite familiar. For example, throughout his terms, Governor Vilsack's (IA) language sounded a familiar ring: "If we are to transition to a new economy and to lead it, we must start by transforming our schools and continue the commitment to excellence and high student achievement" (2001); "...a world-class education is essential to both the economic security of individual lowans and the future economy of our state" (2002); and, "Our children deserve and need a world-class education that pre- pares them for the challenge of global competition" (2005).

Some governors even appeared to use the same speeches from year to year. For example, Governor Barbour's text changed little from 2004 to 2008: "Of course, the mother's milk of economic development is education" (2004); "Education is the number one economic development issue here and everywhere else" (2005); "Education is the number one economic development issue ... in our state" (2006); "Education is the number one economic development issue in Mississippi and in every other state" (2007); "My budget reflects the fact that public education is the number one economic development issue in our state" (2008). The speeches of eight other governors likewise displayed similar textual consistencies from year to year: Alaska, Colorado, Michigan, New Hampshire, New Mexico, New York, Oklahoma, and Pennsylvania.

\section{Phase II}

The similarity across years was confirmed through the regression analyses. As Table 4 (page 9) indicates, only a few of the time variables showed significant differences, and none showed consistent increasing or decreasing trends. The years in the top panel of the table are compared to 2001 as the reference year. The numbers in Table 4 represent unstandardized regression coefficients. The coefficient for economic efficiency for 2002 in the top panel (-.181) indicates that compared to 2001, and after controlling for all other variables in the equation, governors talked less about the economic efficiency purpose. The same was true for 2004 and 2008, compared to 2001. However, the regression coefficient in 2006 for human relationship (.163) indicates an increase in this purpose, compared to 2001. The years in the bottom panel represent the identified yearly pairwise comparisons. As in the top panel, few of the differences are significant and definitive trends are largely absent.

Likewise, there appear to be few regional differences in the purposes governors articulate for education. Governors in southern states, as compared to those in northeastern states (the reference category here), referenced human relationship purposes more often (as indicated by the positive coefficient), but this was the only significant difference. We also 
measured regional differences with different reference regions, the results of which are not reported in the table, but no significant trends were discovered.

Just as the time and regional variables produced a few significant differences, the unemployment, crime, DNSNW, and voter turnout variables showed only one significant relationship. Unemployment appears to be a significant predictor of how often governors discuss economic purposes for education. As the coefficient indicates (.067), as unemployment rates increase, so too do references to the economic purposes for education. None of the other variables, either to the respective conceptually aligned dependent measures or any of the others, showed a significant relationship. Other than economic indicators, this indicates governors likely appear unaffected by their state's circumstances in identifying purposes for education, at least when using these particular independent variables as indicators of state conditions.

Table 4: Time Series Regression Results

\begin{tabular}{lcccc}
\hline & Economic Efficiency & Self-realization & Human Relationship & Civic Responsibility \\
\hline Unemployment & $.067^{*}$ & -.032 & -.000 & -.009 \\
Crime & -2.72 & .412 & -.804 & .425 \\
DNSNW & -.629 & -.399 & -.104 & .242 \\
Voter Turnout & .001 & -.187 & -.080 & -.182 \\
Party & .008 & .024 & $-.024^{*}$ & $-.043^{*}$ \\
2002 & $-.181^{*}$ & -.090 & .020 & -.013 \\
2003 & -.029 & -.036 & .025 & .002 \\
2004 & $-.254^{*}$ & .155 & .038 & -.008 \\
2005 & -.011 & .109 & .032 & .002 \\
2006 & -.137 & $.163^{*}$ & -.001 & -.039 \\
2007 & .029 & .054 & -.015 & -.027 \\
2008 & $-.180^{*}$ & .046 & .014 & -.034 \\
Midwest & .062 & .046 & .016 & .020 \\
South & .148 & .059 & $.049 *$ & -.020 \\
West & .051 & .021 & .035 & -.029 \\
$R_{\text {Adj. }}^{2}$ & .051 & .043 & .009 & .016 \\
\hline 2001 to 2002 & $-181^{*}$ & -.090 & .020 & -.013 \\
2002 to 2003 & .152 & .054 & -.045 & .015 \\
2003 to 2004 & -225 & $.191^{*}$ & .063 & -.010 \\
2004 to 2005 & $.243^{*}$ & -.046 & -.006 & .010 \\
2005 to 2006 & 126 & .053 & -.034 & -.041 \\
2006 to 2007 & .167 & -.108 & -.014 & .012 \\
2007 to 2008 & $-.210^{*}$ & -.008 & .029 & -.007 \\
\hline$* p<.05$ & & & & \\
\hline
\end{tabular}

Significant differences were apparent, however, based on party affiliation. Republican governors referenced human relationship and civic responsibility purposes for education significantly less often than Democrats. This is indicated by the negative coefficients on each, since Democrat was coded as 0 and Republican as 1 for this analysis. Republicans discussed economic purposes more often, but this difference did not reach significance. No significant difference was evident for the self-realization purpose.
Finally, the $R^{2}$ values for these models indicate the variables included here explain little of the variance in the purposes governors assign to education, with figures ranging from less than 1 percent to a little more than 5 percent. However, our purpose in completing this analysis was not necessarily to find an explanatory model as much as it was to examine the elasticity of purpose and discern possible sources for such elasticity. As such, these results suggest inelasticity in the purposes governors assign to educa- 
tion, with economic efficiency showing greater value among governors throughout most of the 2000s regardless of party affiliation, region of the country, or various conditions in their states.

\section{Discussion and Conclusion}

This study examined how U.S. governors, in State of the State speeches from 2001 to 2008, defined the purposes of education in their states. Overwhelmingly, governors defined education by its economic purpose more than any other, both overall and in annual comparisons. The self-realization purpose saw minor attention, while the other two, civic responsibility and human relationship, saw few references. Time series analyses indicated these patterns remained essentially the same regardless of conditions within the states, with the exception of unemployment, where increasing unemployment was related to an increase in references to economic purposes for education. Only a few significant differences were evident based on party affiliation and region of the country.

It is important to bear in mind that findings related to unemployment, crime, DNSNW, and voter turnout may be a function of the variables chosen to represent the respective state conditions. There is always the possibility that replacing the variable of unemployment with, for example, the percentage of the population living at or below poverty could yield different results. Yet most of the variables in this study are frequently used by economists and political scientists as measures of social and economic conditions across states (Tolbert, Lyson, \& Irwin, 1998) and have been used in prior studies on the influence of exigencies on executive speech (Hill, 1998; Ragsdale, 1984). Moreover, most of these are indicators commonly reported in the media and would enjoy salience among policymakers, specifically governors. Thus, it is more than reasonable to expect that if gubernatorial rhetoric about educational purpose were sensitive to exigencies in their state, these make for valid indicators of such.

Although Coffey (2005) found significant differences in gubernatorial ideology based on party affiliation, our results concerning the latter were less definitive than his. Indeed, governors appeared more consistent in the purposes they articulated for education across party and other factors compared to the ideological differences Coffey found. This is likely a function of the different foci between our study and Coffey's and the broader policy content in his analysis compared to ours. Coffey examined ideological differences (liberal, conservative, non-ideological) based on party across 10 different policy domains, some of which are undoubtedly more polarizing than education, thus making the party distinction "easier" to pick up. We, on the other hand, were not so interested in traditional ideological differences but in beliefs about educational purpose, and despite the clear philosophical and ideological differences governors generally hold based on party, the same dynamic is not as salient when discussing the purposes of education in their states.

That most governors would sound similar themes in their SOS speeches likely grows out of at least three realities. First, to think about a purpose of education beyond the most pragmatic, economy, is not standard procedure for policymakers (DiLeo, 1997b), as little reflective thought typifies the policy world (Schon, 1994). Second, state leaders borrow heavily from each other (Mitchell et al., 1985). Rhetoric, laws, and regulations occur in waves as strategies appear successful in one or more states. Third, and likely most influential, is the perception that high-quality education is necessary to ensure economic competitiveness (Doyle \& Hartle, 1985). This was an idea that saw popularization during the 1980s and 1990s, as governors assumed an increasing role in education amidst challenging economic cycles and linked the two in policy and rhetoric (Fusarelli, 2002; Goertz, 1996). As these results indicate, the trend continued into the 2000s, particularly in relation to the "new economy." For scholars such as Fairclough (2001), this is entirely consistent with the growing global importance of the "knowledge-based economy" and new communication technologies.

The emphasis given to economic efficiency over all other purposes carries with it several important implications. First, governors pursue policies and initiatives based on how they define education's purpose. Rhetoric from North Dakota's Governor Hoeven in 2003 illustrates this:

In our budget address last month, we introduced Smart Growth, a new approach to economic development. We started some of 
the initiatives that comprise Smart Growth last session, but we must do more to "Build our Future in North Dakota." Smart Growth is a comprehensive plan that combines education, career development, and technology with entrepreneurial business activity to create a more dynamic economy for North Dakota....We must commit to excellence in education-and making education-K-12, Vocational Education, and Higher Education-an integral part of our economic development efforts-so that our educators become active partners in keeping our young people in North Dakota.

Therefore, given the emphasis placed on economic efficiency, policies such as standards and assessment, accountability, and choice systems will likely continue to see much attention in the United States.

This is not to say, of course, that policies adopted by state legislatures and implemented by various actors (including superintendents, principals, and teachers) will necessarily conform perfectly, if at all, to the gubernatorial purposes that spawned such policies. By the time a policy is carried out, it can be co-opted and molded to the purposes of the implementers. Nevertheless, the agenda-setting function of a governor remains an influential vehicle by which certain purpose-driven policies receive attention and others are completely ignored. And by coupling those purpose-driven policies with stringent accountability measures, governors and other policymakers can increase the fidelity of those policies at the implementation level.

A second implication, related to the first, is that educational goals other than economic ones will quite likely remain marginalized. Throughout the SOS speeches, governors promoted various educational programs and policies to meet economic ends, but only a small number of governors introduced programs related to civic responsibility, human relationship, or self-realization. Kohn (2002b) believes the "reason there seems to be such a consensus on education is that the economic rationale for schooling has triumphed" (p. 5).

Third, the de-emphasis of the other purposes of education carries with it the potential of perpetuating a citizenry committed to self above all, shrugging off responsibilities inherent in a free and pluralistic society. Considering the breakdown of social capital (Putnam, 2000), the disengagement of youth (Chideya, 1997), students' lackluster knowledge of civics (Manzo, 2001), and voter apathy (Piven, 2000), such a dynamic may be in contemporary evidence in the United States.

Finally, given the enthymematic nature of public discourse (Scenters-Zapico, 1994), where a speaker's ideas reflect shared beliefs of the listeners, the definitions governors attach to education call into question the greater public's commitment in the United States to preparing students for more than economic pursuits. Yet it was not always so. In the first volume of Democracy in America, Toqueville (1900) observed the dynamic that he considered central to the strength of the republic in the United States:

It cannot be doubted that, in the United States, the instruction of the people powerfully contributes to the support of a democratic republic; and such must always be the case, I believe, where instruction which awakens the understanding is not separated from moral education which amends the heart. (pp. 322-323)

Today, when education in the United States is defined principally in economic terms, as reflected in gubernatorial rhetoric, and operationalized accordingly with policies, initiatives, and programs, it is a citizenry that appears content to teach its children to prize only shallow pursuits that produce flat, selfindulgent souls and then "wonder at the licentiousness of our times" (Novak, 2002, p. 612).

\section{Future Research}

The directions for future research building from this study are diverse. The most obvious is extending this study by continuing to gather and analyze data as the years progress. This could potentially be quite revealing, as a greater numbers of years will inevitably include various economic and social trends that are not captured in the relatively short time frame covered herein. Second, replicating this study with different economic and social variables would address an aforementioned issue-the validity of particular indicators as representatives of social and 
economic conditions and their relationship to gubernatorial rhetoric.

A third direction, also methodological, would be to reanalyze the gubernatorial speech data inductively rather than deductively, as we did herein. This could confirm the four primary domains we used or discern original themes worthy of further study. Finally, the first decade of the 21 st century saw some tension between the federal and state governments over educational policy. A framework like the one presented here could facilitate a study of the relationship between gubernatorial and presidential rhetoric (and policymaking) similar to Fusarelli (2005).

\section{References}

Annie E. Casey Foundation Kids Count Data Center: http://datacenter. kidscount.org/.

Barber, B. R. (1992). An aristocracy of everyone. New York: Oxford University Press.

Barber, B. R. (1997). Public schooling: Education for democracy. In J. I. Goodlad \& T. J. McMannon (Eds.), The public purpose of education and schooling (pp. 21-32). San Francisco: Jossey-Bass.

Bass, R. V. (1997). The purpose of education. Educational Forum, 61, 128-132.

Beane, J. A. (1998, October). Reclaiming a democratic purpose for education. Educational Leadership, 56(2), 8-11.

Bernick, E. L., \& Wiggins, C. W. (1991). Executivelegislative relations: The governor's role as chief legislator. In E. B. Herzik \& B. W. Brown (Eds.), Gubernatorial leadership and state policy (pp. 73-92). Westport, CT: Greenwood.

Beyle, T. (1999). The governors. In V. Gray, R. L. Hanson $\&$ H. Jacob (Eds.), Politics in the American States (pp. 191-231). Washington, DC: CQ Press.

Boyer, E. L. (1983). High school: A report on secondary education in America. New York: Harper \& Row.

Burden, B. C., \& Sanberg, J. N. R. (2003). Budget rhetoric in presidential campaigns from 1952 to 2000. Political Behavior, 25(2), 97-118.

Butts, R. F. (1975-1976). The search for purpose in American education. The College Board Review, 98, 3-19.

Campbell, J. L. (2002). Ideas, politics, and public policy. Annual Review of Sociology, 28, 21-38.

Carpenter, D. M. (2005). Presidential rhetoric and the purpose of American education. Educational Forum, 69(3), 278-290.

Chideya, F. (1997). Recipe for apathy. Media Studies Journal, 11(1), 82-88.

Child, W. (1994). Causality, interpretation, and the mind. Oxford: Clarendon.
Coffey, D. (2005). Measuring gubernatorial ideology: A content analysis of state of the state speeches. State Politics and Policy Quarterly, 5(1), 88-103.

Conant, J. B. (1959). The American high school today: A first report to interested citizens. New York: McGrawHill.

Conley, D. T. (2003). Who governs our schools? New York: Teachers College Press.

Crew, R. E. (1992). Understanding gubernatorial behavior: A framework for analysis. In T. L. Beyle (Ed.), Governors and hard times (pp. 15-28). Washington, DC: Congressional Quarterly.

Cusick, P. A., \& Borman, J. (2002). Reform of and by the system: A case study of a state's effort at curricular and systemic reform. Teachers College Record, 104(4), 765786.

Davidson, D. (1963). Actions, reasons, and causes. Journal of Philosophy, 60(23), 685-700.

Dewey, J. (1927). The public and its problems. New York: Holt.

DiLeo, D. (1996). Likely effects of devolution on the redistributive character of policy agendas. Spectrum: the Journal of State Politics, 69(3), 6-15.

DiLeo, D. (1997a). Dynamic representation in the American states. State and Local Government Review, 29(2), 98-109.

DiLeo, D. (1997b, September). The political construction of economic development. Paper presented at the annual meeting of the American Political Science Association, Washington, DC.

DiLeo, D. (1997c, April). Politicalculture and dimensions of variation in the content of Governors' speeches. Paper presented at the annual meeting of the Midwest Political Science Association, Chicago, IL.

DiLeo, D., \& Lech, J. C. (1998). Governors' issues: A typology revisited. Comparative State Politics, 19(6), 9-20.

Dometrius, N. C. (1987). Changing gubernatorial power: The measure vs. reality. Political Research Quarterly, 40(3), 319-328.

Doyle, D. P., \& Hartle, T. W. (1985). Excellence in education: The states take charge. Washington, DC: American Enterprise Institute.

Dua, P., Miller, S. M., \& Smyth, D. J. (1999). Using leading indicators to forecast U.S. home sales in a bayesian vector autoregressive framework. Journal of Real Estate Finance and Economics, 18(2), 191-205.

The education governor. (2007). Education Next, 7(3), 1925.

Edwards, R., \& Nicoll, K. (2001). Researching the rhetoric of lifelong learning. Journal of Education Policy, 16(2), 103-112.

Endres, B. (2006). Education for economic life: The role of communicative action. Teachers College Record, 108(10), 2001-2020. 
Engel, M. (2000). The struggle for control of public education. Philadelphia: Temple University Press.

Fairclough, N. (2001). The discourse of New Labour: critical discourse analysis. In M. Wetherall, S. Taylor \& S. Yates (Eds.), Discourse as data. A guide for analysis (pp. 229-266). London: Sage/Open University.

Fairhurst, G. T., \& Sarr, R. A. (1996). The art of framing. San Francisco: Jossey-Bass.

Ferguson, M. R. (2003). Chief executive success in the legislative arena. State Politics and Policy Quarterly, 3(2), 158-182.

Fusarelli, L. (2005). Gubernatorial reactions to No Child Left Behind: Politics, pressure, and education reform. Peabody Journal of Education, 80(2), 120-136.

Fusarelli, L. D. (2002). The political economy of gubernatorial elections: Implications for education policy. Educational Policy, 16(1), 139-160.

Gillies, D. (2008). Quality and equality: The mask of discursive conflation in education policy texts. Journal of Education Policy, 23(6), 685 - 699.

Goetz, S. J., \& Rupasingha, A. (2006). Wal-Mart and social capital. American Journal of Agricultural Economics, 88(5), 1304-1310.

Goertz, M. E. (1996). State education policy in the 1990s. In C. E. VanHorn (Ed.), The State of the States (pp. 179208). Washington, DC: CQ Press.

Goodlad, J. I., Mantle-Bromley, C., \& John, G. S. (2004). Education for everyone: Agenda for education in a democracy. Indianapolis, IN: Jossey-Bass.

Gross, D. A. (1991). The policy role of governors. In E. B. Herzik (Ed.), Gubernatorial leadership and state policy (pp. 1-24). Westport, CT: Greenwood.

Gujarati, D. N. (1995). Basic econometrics (3rd ed.). New York: McGraw-Hill.

Gutmann, A. (1999). Democratic education. Princeton, NJ: Princeton University Press.

Hansen, S. B. (1999). Life is not fair: Governors' job approval ratings and state economics. Political Research Quarterly, 52(1), 167-188.

Hart, R. P. (2000). Campaign talk: Why elections are good for us. Princeton, NJ: Princeton University Press.

Hartoonian, M. (1999). Education for sale: What's a (democratic) principle worth? Social Education, 63(4), 241243.

Heil, J., \& Mele, A. (Eds.). (1993). Mental causation. Oxford: Oxford University Press.

Heller, D. (2007). Curriculum on the edge of survival: How schools fail to prepare students for membership in a democracy. Blue Ridge Summit, PA: Rowman \& Littlefield Education.

Herzik, E. B. (1983). Governors and issues: A typology of concerns. State Government, 54(3), 58-64.
Herzik, E. B. (1991). Policy agendas and gubernatorial leadership. In E. B. Herzik \& B. W. Brown (Eds.), Gubernatorial leadership and state policy (pp. 25-38). Westport, CT: Greenwood.

Herzik, E. B., \& Brown, B. W. (1991). Gubernatorialleadership and state policy. Westport, CT: Greenwood.

Hill, K. Q. (1998). The policy agenda of the president and the mass public: A research validation and extension. American Journal of Political Science, 42(4), 1328-1334.

Holsti, O. R. (1969). Content analysis for the social sciences and humanities. Reading, MA: Addison-Wesley.

Holsti, O. R. (1976). Cognitive process approaches to decision-making: Foreign policy actors viewed psychologically. American Behavioral Scientist, 20(1), 11-32.

Jackson, J. E., \& Kingdon, J. W. (1992). Ideology, interest group scores, and legislative votes. American Journal of Political Science, 36(3), 805-823.

Jacobs, D., \& Carmichael, J. T. (2001). The politics of punishment across time and space: A pooled time-series analysis of imprisonment rates. Social Forces, 80(1), 6189.

Jewell, M. E. (1972). The governor as legislative leader. In T. L. Beyle \& J. O. Williams (Eds.), The American Governor in Behavioral Perspective (pp. 127-140). New York: Harper \& Row.

Jones, K., \& Thomson, P. (2008). Policy rhetoric and the renovation of English schooling: The case of Creative Partnerships. Journal of Education Policy, 23(6), 715-727.

Kaestle, C. F. (1983). Pillars of the republic: Common schools and American society. New York: Hill and Wang.

Kaestle, C. F. (2000). Toward a political economy of citizenship: Historical perspectives on the purposes of common schools. In L. M. McDonnell, P. M. Timpane \& R. Benjamin (Eds.), Rediscovering the democratic purposes of education (pp. 47-72). Lawrence, KS: University Press of Kansas.

Kaplan, D. S., Damphousse, K. R., \& Kaplan, H. B. (1996). Moderating effects of gender on the relationship between not graduating from high school and psychological dysfunction in young adulthood. Journal of Educational Psychology, 88(4), 760-774.

Kelman, S. (1988). Why public ideas matter. In R. B. Reich (Ed.), The Power of Public Ideas (pp. 31-53). Cambridge, MA: Ballinger.

Kingdon, J. W. (1995). Agendas, alternatives, and public policies (2nd ed.). New York: Longman.

Kiser, G. C., \& Monroe, A. D. (1992, March 18-21). State of the state speeches as political documents. Paper presented at the annual meeting of the Southwestern Political Science Association, Austin, TX.

Kohn, A. (2002a). Introduction. In A. Kohn (Ed.), Education, Inc. (pp. 101-104). Portsmouth, NH: Heinemann. 
Kohn, A. (2002b). Introduction: The 500-pound gorilla. In A. Kohn (Ed.), Education, Inc. (pp. 1-12). Portsmouth, NH: Heinemann.

Kunin, M. M. (1990). The rewards of public service. In R. D. Behn (Ed.), Governors on governing (pp. 49-56). Washington, DC: National Governors' Association.

Labaree, D. (1997). Are students 'consumers'? Retrieved February 20, 2003, from http://www.edweek.org/ew/articles/1997/09/17/03labare. h17.html.

Lin, J. (2006). Love, peace, and wisdom in education: A vision for education in the 21st century. Lanham, MD: Rowman \& Littlefield.

Manzo, K. (2001, March 21). 28-nation study: Students' grasp of civics is mixed. Education Week, 20(27), pp. 1, 14.

Marshall, C., Mitchell, D. E., \& Wirt, F. (1985). Assumptive worlds of education policy makers. Peabody Journal of Education, 62(3), 90-115.

Mazzoni, T. L. (1995). State policy-making and school reform: Influences and influentials. In J. D. Scribner \& D. H. Layton (Eds.), The study of educational politics (pp. $53-$ 73). London: Falmer.

McCally, S. P. (1972). The governor and his legislative party. In T. Beyle \& J. O. Williams (Eds.), The American Governor in Behavioral Perspective (pp. 151-169). New York: Harper \& Row.

McDonnell, L. M. (1991). Ideas and values in implementation analysis. In A. R. Odden (Ed.), Education Policy Implementation (pp. 241-258). Albany, NY: State University of New York Press.

Michael, D. L. (2006). Educational reformers or keepers of the status quo: Governors Reubin Askew and Jimmy Carter. Paedagogica Historica, 42(1/2), 211-224.

Miller, N. L., \& Stiles, W. B. (1986). Verbal familiarity in American presidential nomination acceptance speeches and inaugural addresses (1920-1981). Social Psychology Quarterly, 49(1), 72-81.

Mitchell, D. E., Marshall, C., \& Wirt, F. M. (1985). Building a taxonomy of state education policies. Peabody of Journal of Education, 62(3), 7-47.

Moen, M. C. (1988). The political agenda of Ronald Reagan: A content analysis of the State of the Union messages. Presidential Studies Quarterly, 18(4), 775-785.

Morehouse, S. M. (1998). The governor as partyleader: Campaigning and governing. Ann Arbor, MI: University of Michigan Press.

Moses, M. S. (2002). The heart of the matter: Philosophy and educational research. In W. G. Secada (Ed.), Review of Research in Education (pp. 1-22). Washington, DC: American Educational Research Association.

Mourad, R. (2001). Education after Foucault: The question of civility. Teachers College Record, 103(5), 739-759.
Namenwirth, J. Z., \& Lasswell, H. (1970). The changing language of American values: A computer study of selected party platforms. Beverly Hills, CA: Sage.

National Conference of State Legislatures website: www.ncsl.org.

Neuendorf, K. A. (2002). The content analysis guidebook. Thousand Oaks, CA: Sage.

Novak, B. (2002). Humanizing democracy: Matthew Arnold's nineteenth-century call for a common, higher, educative pursuit of happiness and its relevance of twenty-first-century democratic life. American Educational Research Journal, 39(3), 593-637.

Piven, F. F. (2000). Why Americans still don't vote and why politicians want it that way. Boston: Beacon Press.

Postman, N. (1995). The end of education: Redefining the value of school. New York: Knopf.

Proefriedt, W. A. (2001, January 17). Real losses. Education Week, pp. 38, 40.

Putnam, R. (2000). Bowling alone. New York: Simon \& Schuster.

Ragsdale, L. (1984). The politics of presidential speechmaking, 1949-1980. American Political Science Review, 78(4), 971-984.

Ramirez, A., Carpenter, D. M., \& Guzman, N. (2007). Analysis of superintendent search criteria and the standards for administrative preparation programs. In L. K. Lemasters \& R. Papa (Eds.), At the tipping point: Navigating the course for the preparation of educational administrators (pp. 266-278). Lancaster, PA: Proactive Publications.

Rosenthal, A. (1990). Governors and legislators: Contending powers. Washington, DC: CQ Press.

Rupasingha, A., Goetz, S. J., \& Freshwater, D. (2006). The production of social capital in U.S. counties. Journal of Socio-Economics, 35(1), 83-101.

Scenters-Zapico, J. (1994). The social construct of enthymematic understanding. Rhetoric Society Quarterly, 24(3/4), 71-87.

Schon, D. A. (1994). Frame reflection. New York: BasicBooks.

Stateline.org: http://www.stateline.org/live/ViewPage. action?siteNodeId $=152$ \&languageId $=1$ \& contentId $=-1$.

Stemler, S. E. (2004). A comparison of consensus, consistency, and measurement approaches to estimating interrater reliability. Practical Assessment, Research \& Evaluation, 9(4). Retrieved July 9, 2005 from http://PAREonline. net/getvn. asp?v=2009\&n=2004.

Sweeten, G., Bushway, S. D., \& Paternoster, R. (2009). Does dropping out of school mean dropping into delinquency? Criminology, 47(1), 47-91.

Tocqueville, A. C. H. M. C. d. (1900). Democracy in America (H. Reeve, Trans.). New York: P. F. Collier \& Son. 
Tolbert, C. M., Lyson, T. A., \& Irwin, M. D. (1998). Local capitalism, civic engagement, and socioeconomic wellbeing. Social Forces, 77(2), 401-427.

United States Elections Project: http://elections.gmu.edu/index.html.

U.S. Bureau of Labor Statistics: www.bls.gov.

U.S. Census Bureau: http://www.census.gov/geo/www/us_regdiv.pdf.

U.S. Federal Bureau of Investigation's Uniform Crime Reports: http://www.fbi.gov/ucr/ucr.htm.

van Assendelft, L. A. (1997). Governors, agenda setting, and divided government. New York: University Press of America.

Verba, S., \& Orren, G. R. (1985). Equality in America. Cambridge, MA: Harvard University Press.

Weber, M. (1946). The social psychology of the world religions. In H. Gerth \& C. W. Mills (Eds.), From Max Weber (pp. 267-301). New York: Oxford University Press.

Weber, R. P. (1985). Basic content analysis. Beverly Hills, CA: Sage.

Wells, A. S., Slayton, J., \& Scott, J. (2002). Defining democracy in the neoliberal age: Charter school reform and educational consumption. American Educational Research Journal, 39(2), 337-361.

Willis, B. C. (1961). Central purpose of American education. Washington, DC: Educational Policies Commission.

Wingo, G. M. (1965). The philosophy of American education. New York: Heath.

Wixson, K. K., Dutro, E., \& Athan, R. G. (2003). The challenge of developing content standards. Review of Research in Education, 27, 69-107.

Woolf, H. B. (Ed.). (1981). Webster's new collegiate dictionary. Springfield, MA: Merriam.

Yaffee, R. A. (2000). Introduction to time series analysis and forecasting. San Diego: Academic Press.

Yee, A. S. (1996). The causal effects of ideas on policies. International Organization, 50(1), 69-108.

Zoracki, S. M. (2006). Vermont's tradition of education and the Vermont constitution. Albany Law Review, 68(2), 581591.

IJEPL is a joint publication of the Association for Supervision and Curriculum Development, the Faculty of Education at Simon Fraser University, and the College of Education and Human Development at George Mason University. By virtue of their appearance in this open access journal, articles are free to use, with proper attribution, in educational and other non-commercial settings 90 days after initial publication. Copyright for articles published in IJEPL is retained by the authors. More information is available on the IJEPL Web site: http://www.ijepl.org 